\title{
Scrum in Church \\ Saving the World One Team at a Time
}

\author{
Rev. Arline Conan Sutherland \\ First Parish Lexington \\ Lexington, MA USA \\ revasutherland@gmail.com
}

\author{
Jeff Sutherland, Ph.D. \\ Scrum Training Institute \\ Boston, MA, USA \\ jeff@scruminc.com
}

\author{
Christine Hegarty \\ Scrum, Inc. \\ Boston, MA, USA \\ Christine.Hegarty@scruminc.com
}

\begin{abstract}
From 2005-2009 the author led Scrum teams in churches in Massachusetts, Connecticut, Florida, and Delaware. Scrum was designed to increase productivity and improve quality through teamwork. This experience report shows how Scrum was implemented in non-profit organizations to break down silos of knowledge and activity, encourage communication and collaboration, improve the working environment and personal relationships, and drive higher velocity and quality throughout the organization. Nonprofits have impediments that are difficult to overcome - parttime and volunteer workers, narrow specialization, little to no experience with project teams, and political problems whose roots can go back as far as 1692 . Scrum as an institutional change agent is invaluable to a church.
\end{abstract}

Keywords-scrum church impediments transformation

\section{INTRODUCTION}

"Scrum in church? Of course! How else did God create the world in seven days?"

Scrum was invented by developers to facilitate their work. They used a language and a model that described their environment. For the last five years, I have been working to translate that language and apply it in a very different context, Unitarian Universalist congregations.

Being married to one of the creators of Scrum has helped a lot. He has a certain investment in my work both as a spiritual leader and in the part of my work not often taught at Divinity School: managing a staff and implementing the goals and vision of the congregation.

\section{THEOLOGY AND SCRUM}

Theology is often defined as words about God, but as Prof. Conrad Wright constantly emphasized, the ways we humans organize ourselves reflect our theology [1]. We are encouraged to find multiple metaphors to express a variety of concepts of God such as Reality and Mystery, Father and Mother - each one of which is inadequate. We are taught to become aware of how we construct our view of the world and to open our eyes to other ways of interpreting reality. One example is the old adage that if the only tool one has is a hammer it is hard to imagine uses not limited to pounding.

The ways we organize ourselves, the structures we create to order our lives, and our work, reflect our deepest theological understandings. How is power understood? Does it flow from on high? Does it emerge from the people? Does it take a completely different configuration? Who benefits? What is most highly valued? What cognitive styles are preferred? What or who is on the margins? What is not seen because it cannot be imagined? Who is not "like us"? How do we treat them?

One of my favorite questions as I enter a congregation is "How does power flow around here?" One answer I'll never forget is, "Well, it's sorta like water in a bathtub, it sloshes." We laugh, perhaps in recognition?

In short, the ways we live, what we do, and how we do them reflect one's deepest values. Scrum is much more than a cool way to develop software. It is a world view; it offers ways of conceiving and structuring all the ways we interact.

\section{WHAT'S A CHURCH?}

Organizationally, churches in most faith traditions are non-profits and depend on a pool of volunteers, the care and feeding of whom present particular challenges and opportunities. There is a board composed of volunteers from the congregation, One or two ministers or lay employees work as directors of various programming areas such as preaching, designing worship, pastoral care, children and youth, membership development, social justice, and music. The administrative office handles finances, supervises the staff and volunteers, prepares a monthly newsletter, maintains the building and grounds, and coordinates fundraising to support the institution.

The Unitarian churches in New England evolved out of the Puritan churches that founded the Massachusetts Bay Colony. Years later, Harvard, a university older than the United States, was established to provide a learned ministry and gave the Unitarians an intellectual grounding. In the early days, the New England town meeting was the way things were organized, and the church was the center of life in the town and facilitator of the democratic process. My predecessor at First Parish Lexington helped foment the American Revolution, the first battle was fought on the church green, the first British soldier killed died in the sanctuary, and he remains buried on church grounds to this day. Given this history, it follows that freedom, democracy, and intellectual rigor are deeply embedded in the Unitarian tradition. They fought for those ideals in the revolution and 
they died for them in Selma, Alabama during the Civil Rights Movement. To them, when Scrum advocates truth, transparency, and trust, it goes hand in hand with freedom, democracy, community, and personal responsibility for making the world a better place.

Congregations come in a variety of sizes and shapes with different staffing configurations and resources. Larger congregations, such as the one I served in Wilmington, DE with more than 500 members, have a staff of two full-time ministers, a full-time director of religious education, a fulltime director of music, a part-time director of volunteers and membership, a full-time business manager, a full-time administrative assistant, a full-time building manager, a halftime person who handles accounts receivable and payable, and a part-time custodian.

\section{IV. SCRUM IN FOUR CHURCHES:}

In my last four churches, I served as Interim Senior Minister, hired by the board for a period of one or two years between longer-term settled ministers. I am trained to be a change agent and assist the church during a leadership transition. The church must grieve their losses and celebrate their accomplishments in order to acquire a new sense of identity. Emergence of new leadership must be encouraged along with strengthening the relationship of the church with the larger denomination resources. The church is repositioned to smooth the way for a new settled minister. Scrum is a tool that can support the institutional change required.

\section{A. Hartford}

I first introduced Scrum in the Unitarian Society in Hartford, CT, a congregation of about 250, with three fulltime staff: Business Manager, Director of Religious Education, and the Parish Minister. Three half-time employees completed the staff. As I spoke with Jeff about my struggles to understand what was going on and how to manage the staff, he kept suggesting that using Scrum could help. I invited him to come to the church for a four-hour conversation and presentation to the staff. The board chair attended for the last hour.

Board members are by definition members of the congregation and almost all have day jobs outside the church. Very few of them, at least initially, saw much value in Scrum. Therefore, I have used it almost exclusively with the staff.

In Hartford, I quickly realized the need to adapt Scrum to the environment. There is no one size fits all model. The whole staff could only meet once a week. We used the format of asking the three questions each week: "What did you do last week?" "What will you be doing this week?" and "What impediments did you encounter?"

The subgroup that worked together daily in the office had a history of working collaboratively, which ironically hid some impediments. I discovered only as I was about to leave that the daily office team was not holding 15 minute standups four days a week; they were in fact not meeting at all. They did all work in the same large room, where they could hear one another.
The constructs and language of Scrum allowed me to identify bottlenecks and to tell the board about the impediments I saw. Entrenched volunteers and staff, a major issue in all the congregations in which I have worked, are highly invested in doing things the way they have always done them. Many members feel deep loyalty to them. Some of these folk are very competent - those people one can usually work with. The less competent people or those whose abilities are diminishing are a problem of a completely different category. This is not a dynamic unique to churches. Addressing them can cause an uprising. Many a minister has lost his/her job after doing so. It's a little easier for an interim minister. Objectively demonstrating to the board and others how the impediment posed is negatively affecting the system is critical.

At my last board meeting in Hartford, I mentioned yet another entrenched but unspoken issue as an impediment. It was greeted at first with silence and then with laughter as the board chair announced, "Arline, I think you have pulled every last skeleton out of the closet!"

As that ministry concluded, I attended Scum Master Training where I began to realize how much more effectively the process could be implemented.

\section{B. Fort Meyers}

The following year found me in Fort Meyers, Florida, a very different environment. Not only is it located in the subtropics, a sharp contrast to New England weather, the majority of the congregation are retirees. Some live in Florida year round; a significant number are there only in the winter. The congregation is working to develop more of a presence in the community for whom Fort Meyers is the place they live and work and raise their children.

The full-time staff are the long time, very capable Administrator and the Minister. The Director of Religious Education and the Music Director are $1 / 4$ time. Jeff offered a one-day Scrum workshop. Surprisingly, in addition to the staff, $20 \%$ of the membership attended. The biggest impact was energizing the volunteers, at least six of whom donated as many as ten hours a week. Others gave three or four. The workshop participants identified their top priorities and organized teams to work on them. Representatives of the teams working on the top priorities then attended a monthly Scrum of Scrums with the staff. The structured accountability and recognition of effort made a huge difference to the morale and to the work accomplished.

The year following my departure, the Membership Team sent me their annual report, identifying their success and fun in attracting new members with their drastically adapted use of Scrum.

\section{Wilmington}

The First Unitarian Church in Wilmington, DE is a congregation of about 500 members with several full-time clergy and administrators. When I first talked to the board about Scrum, most felt that Scrum would be a distraction. On the other hand, they pointed out that as policy board they would not interfere with the staff, so I had a free hand. 
Once again, Jeff came to train the staff. (There are definite advantages to being his wife.) Two Unitarian Universalist ministers from Richmond VA that had professional Scrum Masters in their congregations came too. Their outside presence changed the dynamics of the group by bringing a broader perspective and gave credibility to Scrum.

The program staff were resistant to using Scrum. The business manager and the office staff were less so. The reasons are interesting. The program staff are specialists in their own areas, but their work intersects in places. The preacher and the musicians, for instance, work together to craft a worship service, but the skills are radically different. It's parallel play. They have no concept of working as a team in the way Scrum can make possible.

The people running the office have a clearer vision of how they work as a team. The overall goal is more concrete. Their tasks are more interdependent, and there are more overlapping skill sets. The Business Manager became an enthusiastic Scrum convert with a Scrum board in her office separate from the one in the front office that was visible to everyone who entered the church.

A core strategy used in all my churches and used by Jeff at the Scrum Training Institute when coaching CEOs is to put the organization on a release plan like a new software product. Every quarter, the organization gets better. What are the new features? Most current activities in an organization are maintenance activities, not building new organizational capabilities. To drive new initiatives, Jeff's recommendation is to strive to have the top $20 \%$ of the Product Backlog be new features and only $80 \%$ ongoing maintenance of known processes [2]. Let low priority items fall off the Product Backlog.

With this in mind, we separated out two areas: keeping the engine running and new initiatives. We never came close to dedicating $20 \%$ of our time to new features but the distinction was illuminating. It also helped us to explain and visually demonstrate to stakeholders what we were doing with our time. Improving velocity of course created more space for new initiatives than we had previously.

For a variety of reasons, including the disruptive dismissal of the previous business manager, there was a huge technical debt, which at times was depressing. We called it the can of worms. As soon as one tried to do something, which invariably looked simple, it was discovered that there were no procedures or systems. Documenting the work and watching the level of debt decrease was a major morale booster.

One thing we learned is that when stories are broken down sufficiently it's easier to see how we could help one another. The Christmas Eve bulletins for the two services became a case in point. The woman in charge of producing them was working around the clock. The rest of us gave her the information about our pieces and then went off to create them or to rehearse. At the stand up I asked, "What is going on here? She was here until ten o'clock; the rest of us were out of here at four o'clock." Part of that was as a new hire she felt that her job and her reputation were on the line. But did the rest of us ask what we could do to help? We did not see it as having anything to do with us. It wasn't "our job."
Each and every one of us could have helped. And in the end, we did. I mean, one of the tasks is folding and inserting pieces of paper. Even I can do that!

Staff morale became high. All sorts of people commented on how welcome it was to hear laughter in the hallways.

As I said earlier, most board members were highly skeptical of Scrum. Nevertheless many of them attended stand-ups as curious observers. They were amused and fascinated by the energy and increased sense of teamwork that was created. They also could observe staff dynamics and performance for themselves.

\section{Lexington}

First Parish in Lexington, MA is the historic, whitesteepled church on the Battle Green where the shot heard round the world was fired. There are currently about 300 members. The full-time staff includes the Minister, the Director of Religious Education, and an Administrator. The Music Director, the Building Manager, and a book-keeper comprise the part-time staff.

Implementing Scrum here has been more difficult than in any of the other congregations. A long and proud history does not always create an environment where change is welcome. Doing things the way we have always done them is deeply embedded in the culture. Self-appointed volunteers have been running various areas for decades if not centuries and continue to do so, often undermining staff and ignoring board policies in the process. Fierce independence is a longstanding tradition in Lexington. This, combined with a mixed array of previous ministers ranging from extreme micro-management to extreme laissez-faire, creates deepseated systemic issues.

The law in Scrum that nothing new can interrupt a sprint plays havoc with the life of a minister. Although sprint length can be shortened in an environment with constant change, the staff can only effectively wrestle with a weekly sprint and unanticipated short-term emergencies happen every day! People die. Pastoral emergencies emerge. These cannot be scheduled and inevitably cluster. One colleague is conducting two memorial services and a wedding this weekend, and then on Sunday he is preaching. After the service he is giving his report at the Annual Meeting. There have been a series of such interruptions. We are in the process of systemizing our response and the required triage. Mundane issues such as a policy for closing the building or canceling services in snowstorms and communicating those decisions still have to be addressed in the midst of more serious concerns.

Scrum encourages people to say what they really want and to set priorities. This is hard! There are competing goals and values. Especially when resources are tight, people fight over shrinking pieces of the pie.

Another reality of church life is the difficulty of holding daily stand-ups. Many employees are part-timers and are not in the office every day. Staff who work on Sundays, usually take a day off during the week. Creative work such as crafting a service and writing a sermon is best done uninterrupted in a home study or behind a closed door. Physically gathering everyone for fifteen minutes at ten 
o'clock Monday through Friday does not work unless a critical majority can be there more days than not.

Adaptations we are experimenting with include the use of technology like Skype. Since the largest demographic using Skype are grandparents, even older, less technologically sophisticated members are often skilled users.

\section{LEARNINGS:}

One of the benefits of introducing Scrum in multiple, diverse settings has been to see how the unique environments force adaptations. For many years I was disappointed at what I perceived as my failure to run a "real scrum." It took time, Ken Schwaber's admonitions, and Steve Denning's feedback [3] to realize that each and every time Scrum is introduced into a system it has to be adapted. This is a critical insight!

Here are some of aspects of Scrum I have found work in each environment:

\section{A. Scrum as an Agent of Change}

It is hard to overemphasize the shift in thinking when one moves away from identifying and fixing problems to actively seeking impediments. It's moving from blaming and shaming to naming and claiming responsibility. This profound attitudinal movement is essential to Scrum.

As Steve Denning writes [3], "Impediments imply that we have a shared goal and helps focus the discussion on how we could remove this thing that is getting in the way of accomplishing what we all want to achieve. By contrast, discussion of 'problems' can be multi-directional and can end up like a circular firing squad."

\section{B. Working as a Team}

Doing Scrum with staff even when the only meetings are once a week and an hour long helps people gain an image of themselves as a team rather than as siloed programs that have little to no overlap. Team building occurred in every setting. Staff reported that sometimes to their surprise seeing one another's "to do lists" enabled them to more fully understand the scope of their colleagues' work. Often various staff people can offer assistance to one another in ways neither would have imagined. This was often the result of granulating tasks into small increments. The discipline of not only meeting regularly but also using the format of answering the three questions organized people's thinking.

\section{Transparency}

Visibility is essential! Having Scrum boards up and relatively easy to read is invaluable. Team members need to see what is really going on. So does the rest of the system: the board and other church members.

\section{Clarity and Focus}

The amount of time, energy, and money it takes to run a church becomes clearer. While none of the teams were able to devote only $80 \%$ of their time to the routine "keeping the engine running" tasks and use $20 \%$ of their time working on new features, the concept was valuable in differentiating the two aspects of our work.

\section{E. Flexibility in Vocabulary}

Vocabulary can be a stumbling block. Many church people associate words such as "product owner" and "value added" as tools of a business or corporate environment that are at best suspect. "We are a church," they protest, "not Microsoft or a bank!" I have experimented with "vision holder" to describe the product owner. The word "Scrum" is rarely objected to nor is "Scrum Master."

\section{F. Iterations and Continuous Improvement}

The concept of iterations in which one is continually inspecting and adapting is invaluable. This practice encourages experimentation and it builds in continued learning.

\section{CONCLUSIONS}

Scrum is applicable in many environments. It is not restricted to software development. If it can work in a church, it can work almost anywhere. As environments shift, necessary adaptations become evident. New environments may reveal new opportunities and add dimension to Scrum practices.

Scrum can be far more than a process for technical change and development. Practicing Scrum can lead to genuine adaptive change so that the organization is continually evolving and transcending the restrictions and limitations of any particular worldview. Room can be created in which diverse multicultural perspectives add to the whole. As Scott Page [4] points out, "Cognitive diversity is key." Learning to appreciate and work with people who are not like us expands our cognitive horizons and enables naming or diagnosing problems. It then provides groundwork for solving them when we could otherwise not even be able to recognize they existed.

\section{REFERENCES}

[1] C. Wright, Congregational Polity: A Historical Survey of Unitarian and Universalist Practice. Boston: Skinner House Books, 1997.

[2] J. Sutherland and I. Altman, "Take No Prisoners: How a Venture Capital Group Does Scrum," in Agile 2009, Chicago, 2009.

[3] S. Denning, "Impediments are shared goals-problems become circular firing squads," A. Sutherland, Ed. Somerville, MA, 2009.

[4] S. Page, The Difference: How the Power of Diversity Creates Better Groups, Firms, Schools, and Societies: Princeton University Press, 2007. 